\title{
Benthic macroinvertebrate functional diversity regulates nutrient and algal dynamics in a shallow estuary
}

\author{
Natalie A. McLenaghan ${ }^{1,3, *}$, Anna Christina Tyler ${ }^{1}$, Ursula H. Mahl' ${ }^{2}$, \\ Robert W. Howarth ${ }^{2}$, Roxanne M. Marino \\ ${ }^{1}$ Department of Biological Sciences, Rochester Institute of Technology, Rochester, New York 14623, USA \\ ${ }^{2}$ Department of Ecology and Evolutionary Biology, Cornell University, Ithaca, New York 14853, USA \\ ${ }^{3}$ Present address: College of Forestry and Conservation, University of Montana, Missoula, Montana 59812, USA
}

\begin{abstract}
Proliferation of macroalgal blooms is regulated by grazing pressure and nutrient availability, which may be mediated directly by benthic macroinvertebrates or indirectly through feedback mechanisms. Using invertebrates common to a shallow estuary in Cape Cod, Massachusetts (USA), we determined effects of faunal diversity on benthic microalgae, net ecosystem metabolism, sediment nutrient fluxes, and macroalgal biomass and productivity. Laboratory microcosms contained sediments with single- and mixed-species invertebrate assemblages, in the presence of (1) no macroalgae, (2) a macroalgal monoculture, and (3) a realistic macroalgal polyculture. The depositfeeding gastropod Ilyanassa obsoleta suppressed benthic microalgae, enhanced nitrate efflux from sediments, and maintained macroalgal standing stocks. Conversely, the burrowing, omnivorous polychaete Alitta (formerly Nereis) virens stimulated benthic microalgal growth, inhibited efflux of ammonium, and drastically reduced macroalgal biomass via grazing and translocation of thalli below the sediment surface. In the polyculture experiment, A. virens sequentially removed Gracilaria sp. (Rhodophyta), Ulva sp. (Chlorophyta), and finally Fucus vesiculosus (Phaeophyta). The bivalve Mya arenaria exhibited limited effects on benthic dynamics. In mixed-fauna assemblages, biomass and productivity of benthic microalgae and macroalgae were consistently lower than predicted, revealing non-additive effects of biodiversity. Communities dominated by I. obsoleta or other surficial grazers could indirectly promote macroalgal blooms via sustained release of sediment-derived nutrients and reduction of benthic microalgae. In contrast, omnivorous burrowers such as $A$. virens may buffer symptoms of eutrophication through inhibition of ammonium supply and direct grazing of bloomforming macroalgae. Overall, our results highlight species-specific effects on key ecosystem functions, and demonstrate important feedbacks between top-down and bottom-up controls in shallow estuaries.
\end{abstract}

KEY WORDS: Benthic invertebrates $\cdot$ Macroalgae $\cdot$ Benthic microalgae $\cdot$ Nutrient supply $\cdot$ Grazing Biodiversity $\cdot$ Ecosystem function $\cdot$ Eutrophication

\section{INTRODUCTION}

Macroalgal distribution and abundance in shallow estuaries is regulated by a complex suite of biotic and abiotic factors that incorporate feedbacks with resource availability and consumer pressure (Valiela et al. 1997,
Hauxwell et al. 1998, Worm et al. 2000), coupled with competition among autotrophs (Havens et al. 2001, Sundbäck et al. 2003). In shallow coastal systems, accelerated nutrient loads have alleviated limitation of primary production (Howarth 1988) and prompted the proliferation of ephemeral seaweeds capable of dimin- 
ishing or replacing perennial macroalgae, seagrasses, and benthic microalgae (Valiela et al. 1997 and references therein). In concurrence with allochthonous inputs, macroalgal growth can be fueled by nutrient regeneration from underlying sediments (Sundbäck et al. 2003, Tyler et al. 2003, Kamer et al. 2004). This internal loading to bottom waters is controlled by a number of linked indirect and direct factors, including macroinvertebrates and benthic microalgae.

Sediment biogeochemical processes are strongly regulated by bioturbation and irrigation of biogenic structures (Rhoads 1974), and mediation of solute fluxes may vary according to invertebrate functional characteristics (Mermillod-Blondin et al. 2004, Karlson et al. 2005) that relate to feeding behavior and mobility within the benthos. Nereidid polychaetes dwelling in burrows, for example, can flush porewater ammonium to the water column (Andersen \& Kristensen 1988, Michaud et al. 2006) and stimulate coupled nitrification-denitrification (Henriksen et al. 1983), while bioturbators active near the sediment surface, such as mollusks and tubiculous amphipods, may enhance oxygen penetration and thereby impact mineralization processes (Henriksen et al. 1983, Mermillod-Blondin et al. 2004, Michaud et al. 2006). Nutrient regeneration may further be mediated by benthic microalgal communities that intercept nitrogen $(\mathrm{N})$ and phosphorus (P) at the sediment-water interface (Sundbäck et al. 1991, Tyler et al. 2003), stimulate nitrification potential (An \& Joye 2001), and either augment or inhibit $\mathrm{N}$ removal by modifying denitrification rates (Rysgaard et al. 1995, Sundbäck et al. 2004). While a limited number of investigations have explicitly tested effects of species or functional diversity on biogeochemical cycling in marine systems (e.g. Emmerson et al. 2001, Waldbusser et al. 2004, Norling et al. 2007), the need remains for greater empirical understanding of complex interactions across multiple trophic levels (Bruno et al. 2008).

In conjunction with controls on sediment properties and nutrient supply, benthic fauna may also exert direct pressure on seaweed growth via top-down reduction of biomass (Hauxwell et al. 1998, Worm et al. 2000). Furthermore, invertebrates can influence macroalgal community structure and diversity through preferential consumption of palatable, annual taxa (Lubchenco 1978) with high nutrient content and negligible defense compounds (Hay \& Fenical 1988). Most research to date, however, has focused on the roles of crustaceans and gastropods as dominant seaweed grazers. The few studies that have examined top-down impacts of omnivorous polychaetes (e.g. Raffaelli 2000, Nordstrom et al. 2006, Engelsen \& Pihl 2008) did not explore effects within diverse faunal or macroalgal assemblages.
Our study investigated feedbacks between biodiversity and ecosystem functioning as related to bottom-up and top-down controls on algal growth. The approach employed a series of microcosm experiments representing a shallow, temperate estuary undergoing rapid eutrophication. We hypothesized that the functional characteristics of common invertebrates would differentially influence net ecosystem metabolism, nutrient supply, and biomass of benthic microalgae and macroalgae. Moreover, we tested the relationship between functional diversity and ecosystem processes in multispecies assemblages of both fauna and seaweeds.

\section{MATERIALS AND METHODS}

Site and organism descriptions. West Falmouth Harbor ( $\mathrm{WFH}_{;} 41^{\circ} 36^{\prime} \mathrm{N}, 70^{\circ} 38^{\prime} \mathrm{W}$ ) is a shallow, polyhaline (from 20 to 30 ppt) embayment in SW Cape Cod, Massachusetts (USA), with an average depth of $0.6 \mathrm{~m}$ at mean low water (Howes et al. 2006). Since 1994, migration of a localized wastewater plume into the harbor has doubled the current $\mathrm{N}$ load compared with background levels (Howes et al. 2006). In the degraded inner reaches of the estuary, macroalgal standing stocks are dominated by annual, opportunistic seaweeds during early summer, although perennial fucoids are still present (K. McGlathery and A. C. Tyler unpubl. data). Macroalgae used in the current study included the following co-occurring taxa: the rhodophyte Gracilaria sp. (Gracilariaceae; hereafter Gracilaria), the (laminar form) chlorophyte Ulva sp. L. (Ulvales; hereafter Ulva), and the phaeophyte Fucus vesiculosus L. (Fucales; hereafter Fucus). We selected 3 macroinvertebrate species common to the WFH benthos (McLenaghan 2009, T. Duncan pers. comm.), each with a cosmopolitan distribution along the NW Atlantic coast (Gosner 1971). Ilyanassa obsoleta Say, the eastern mudsnail, inhabits the sediment-water interface and is a mobile, omnivorous deposit-feeder that primarily consumes micro-flora and -fauna (Curtis \& Hurd 1979). Mya arenaria L., the soft-shelled clam, is a sub-surface $(<8 \mathrm{~cm}$ depth) suspension-feeder. Alitta (formerly Nereis) virens Sars, the king ragworm, constructs and irrigates semi-permanent burrows and exhibits a diverse diet that includes detritus, benthic microalgae, macroalgae, and fauna (Pettibone 1963).

Microcosm set-up and experimental design. For all experiments, we constructed microcosms in transparent, polycarbonate tubes (i.d. $=9.5 \mathrm{~cm}$, length $=30 \mathrm{~cm}$ ), sealed at the bottom with rubber stoppers. Finegrained sands were collected from WFH using coretubes and were partitioned into 3 depth intervals (from 0 to 2 , from 2 to 5 , and from 5 to $13 \mathrm{~cm}$ ). To avoid downward mixing of surface biota and organic matter, 
respective vertical sections were sieved (1 $\mathrm{mm}$ mesh) and homogenized separately prior to reconstruction. Organic matter (OM) content of surface sediments (from 0 to $2 \mathrm{~cm}$ ) was $1.3 \%$ in 2007 and $0.7 \%$ in 2008 (loss-on-ignition at $500^{\circ} \mathrm{C}$ ). Tubes were wrapped with opaque material below the sediment-water interface to inhibit light penetration at depth, then incubated in indoor, flowing seawater tables (from 28 to $30 \mathrm{ppt}$; from 17 to $20^{\circ} \mathrm{C}$ ) with full-spectrum fluorescent bulbs on a 14 h light:10 h dark (14:10 L/D) daily photoperiod. Photosynthetically active radiation in experiments (sediment surface: $200 \mu \mathrm{mol} \mathrm{m} \mathrm{m}^{-2} \mathrm{~s}^{-1}$; LI-192 underwater quantum sensor, LI-COR®) was consistent with the lower range of daytime light levels in WFH (M. Hayn pers. comm.), and an integrated aeration system enhanced water mixing in each microcosm and ensured adequate oxygenation. We augmented surficial sediments with oven-dried $\left(60^{\circ} \mathrm{C}\right)$, finely ground macroalgal thalli collected from WFH (100 g dry weight $[\mathrm{dwt}] \mathrm{m}^{-2}$ ) to simulate deposition of a moderatesized bloom (Hauxwell et al. 1998). Prior to organism additions, microcosms were acclimated for $\sim 3 \mathrm{wk}$ (see timeline in Fig. 1).

We executed the first and second experiments (Expt I and Expt II, respectively) simultaneously from June to July 2007, and the third experiment (Expt III) from June to August 2008. In Expt I, we investigated invertebrate regulation of nutrient fluxes, net ecosystem metabolism, benthic microalgae, and $\mathrm{N}_{2}$ fixation in microcosms with sediments but without macroalgae. Expts II and III explored faunal effects on the biomass, productivity, and nutrient content of macroalgae, using a seaweed monoculture (Gracilaria; Expt II) and a seaweed polyculture (Gracilaria, Ulva, and Fucus; Expt III). Treatments included defaunated controls and single- and mixed-species invertebrate additions.

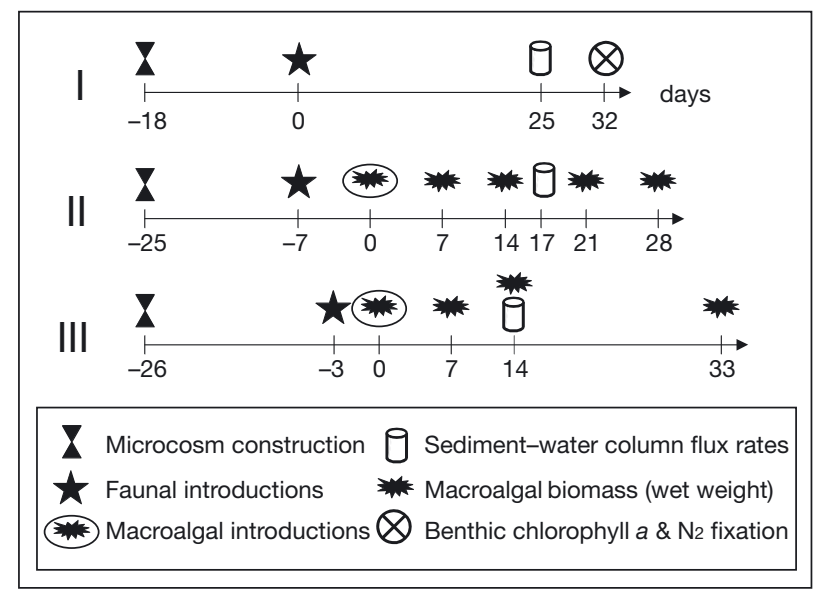

Fig. 1. Timelines for procedures (left column in key) and measurements (right column in key) in Expts I to III. 'Day 0' marks introduction of fauna in Expt I, while 'Day 0' in Expts II and III marks introduction of macroalgae
Expts I and II each contained Ilyanassa obsoleta ('Ilyanassa' treatment; 430 ind. $\mathrm{m}^{-2}$ ), Mya arenaria ('Mya' treatment; 290 ind. $\mathrm{m}^{-2}$ ), and Alitta virens ('Alitta' treatment; 290 ind. $\mathrm{m}^{-2}$ ) in monospecific microcosms and in a 3-species assemblage ('Mix' treatment; 430 ind. $\left.\mathrm{m}^{-2}\right)(\mathrm{n}=4)$. Expt III consisted of I. obsoleta (Ilyanassa; 860 ind. $\mathrm{m}^{-2}$ ) and A. virens (Alitta; 290 ind. $\mathrm{m}^{-2}$ ) in 1- and 2-species (Mix; 570 ind. $\mathrm{m}^{-2}$ ) treatments ( $\mathrm{n}=5$ ). We equalized microcosms according to total organism biovolume (Expts I and II $=4.6 \pm 0.3 \mathrm{ml}$; Expt III = $7.3 \pm 0.5 \mathrm{ml}$ ). See McLenaghan (2009) for relative abundances of invertebrates used in experiments and in WFH, and Michaud et al. (2006) for justification of using biovolume as a means to compare faunal treatments. Following a 4 d laboratory acclimation in WFH sediments, fauna were introduced to microcosms and they burrowed immediately. Macroalgae were collected manually, rinsed to remove epibiota, and acclimated in seawater tanks for $5 \mathrm{~d}$ prior to inclusion in experiments. Initial wet weights (wwt) per microcosm (Expt II: 4.65 g; Expt III: $1.45 \mathrm{~g} \mathrm{species}^{-1}=4.35$ total g) corresponded to densities in local estuaries with moderate nutrient loads (Hauxwell et al. 1998). We secured screens (5 mm mesh) atop each microcosm to prevent faunal and macroalgal migration; screens did not substantially impede light penetration.

Sediment-water column nutrient and oxygen exchange. In Expt I, flux rates of dissolved inorganic nitrogen $\left(\mathrm{DIN}=\mathrm{NO}_{2}{ }^{-}+\mathrm{NO}_{3}^{-}\right.$[hereafter, $\left.\mathrm{NO}_{3}{ }^{-}\right]$and $\mathrm{NH}_{4}{ }^{+}$), $\mathrm{PO}_{4}{ }^{3-}$, and dissolved $\mathrm{O}_{2}$ (DO) were measured on Day 25. DO fluxes (only) were recorded 17 and $14 \mathrm{~d}$ following addition of macroalgae in Expts II and III, respectively. We incubated microcosms according to Tyler et al. (2001), with dark conditions preceding light conditions. Overlying water was carefully siphoned and refilled with fresh seawater prior to sealing with a gas-tight lid, and mixing was maintained with a Tefloncoated magnetic stir-bar (60 rpm) suspended in the water column of each microcosm. Seawater-only microcosms were analyzed simultaneously to correct for water-column activity. DO measurements (WTW Oxi 330i meter with galvanic probe for Expts I and II; Hach HQ40d meter with LBOD101 probe for Expt III) were recorded regularly to prevent depletion. Water samples for nutrient analyses were filtered immediately $\left(0.45 \mu \mathrm{m}\right.$; Whatman GF/F) and $\mathrm{NH}_{4}{ }^{+}$reacted within $1 \mathrm{~h}$ of collection using the phenol-hypochlorite method (Solorzano 1969). $\mathrm{PO}_{4}{ }^{3-}$ was analyzed according to Murphy \& Riley (1962) and $\mathrm{NO}_{3}{ }^{-}$samples were frozen $\left(-40^{\circ} \mathrm{C}\right)$ prior to measurement on an Alpkem 'continuous flow' Autoanalyzer (OI Analytical). Hourly flux rates across the sediment-water interface were calculated based on changes in concentration over time, with corrections for water-column activity and seawater replacement following sample extraction (see Tyler et al. 
2001). Gross primary productivity (GPP) was determined by subtracting hourly rates of benthic oxygen consumption (BOC) measured in the dark from hourly flux rates in the light. Net ecosystem metabolism (NEM) represents the combined daily total of light and dark fluxes. We used a seasonal 14:10 L/D photoperiod to estimate daily GPP, BOC, and NEM. Our calculations assume constant daily rates of community $\mathrm{O}_{2}$ consumption and thus do not account for possible diurnal variability. For Expts II and III, GPP values reflect the combined productivity of macroalgae and benthic microalgae. Potential DIN assimilation by benthic microalgae in Expt I was calculated using 80\% GPP and carbon (C):N of 9:1, according to Sundbäck et al. (2004).

Benthic microalgal biomass and $\mathrm{N}_{2}$ fixation rates. After 32 d, sediments from Expt I were extruded, sectioned and homogenized, then sub-sampled for benthic photopigments (from 0 to $1 \mathrm{~cm}$ ) and $\mathrm{N}_{2}$ fixation rates (surface: from 0 to $1 \mathrm{~cm}$; sub-surface: from 3 to $4 \mathrm{~cm}$ ). Samples for photopigment analysis were frozen $\left(-80^{\circ} \mathrm{C}\right)$ in darkness prior to spectrophotometric measurement (Strickland \& Parsons 1972), and concentrations calculated according to Lorenzen (1967). Benthic chlorophyll a ( $\mathrm{chl} \mathrm{a}$ ) was used as a proxy for biomass of photosynthetic microalgae, and chl a: phaeopigments (natural degradation products of chl a) provided an indication of microalgal turnover. $\mathrm{N}_{2}$ fixation rates were determined on a subset of treatments (surface: control, Ilyanassa, Alitta; sub-surface: control, Alitta). Assays utilized the acetylene-reduction method with the slurry technique (Stewart et al. 1967) under the following sediment incubations: light $\left(280 \mu \mathrm{mol} \mathrm{m} \mathrm{m}^{-2} \mathrm{~s}^{-1}\right.$; surface only), dark, and dark + sodium molybdate (+Mo: $40 \mathrm{mM}$ $\mathrm{Na}_{2} \mathrm{MoO}_{4}$ ). Molybdate is a specific inhibitor of sulfate reduction (Smith \& Klug 1981), and its inclusion enables evaluation of sulfate-reducing bacteria contributions in $\mathrm{N}_{2}$-fixing communities. Detailed assay methods are described in McLenaghan (2009).

Macroalgal properties. Macroalgal biomass was measured periodically (see Fig. 1) by temporarily removing thalli from microcosms, rinsing in seawater and blotting with paper towels, and recording wwt. At the end of experiments, thalli were briefly rinsed in deionized water and oven-dried $\left(60^{\circ} \mathrm{C}\right)$ to obtain dwt. When sufficient biomass remained, macroalgae were finely ground to determine tissue $\mathrm{C}$ and $\mathrm{N}$ content (Carlo-Erba NA-2500 Elemental Analyzer).

Data analysis. Effects of faunal treatments were evaluated with ANOVA (SPSS 11.0) after checking for normality (Shapiro-Wilk's test) and homogeneity of variance (Levene's test). Data were transformed if assumptions were violated. When significant effects were established ( $p<0.05)$, we used post hoc pairwise comparisons (Tukey's HSD) to determine treatment differences. One-way ANOVA was used for benthic photopigments, macroalgal biomass and tissue nutrients, GPP, BOC, and NEM. Two-way ANOVA was performed for $\mathrm{N}_{2}$ fixation and nutrient flux rates, with faunal treatment and incubation condition as fixed and interaction factors. Macroalgal biomass data did not consistently achieve normality or homoscedasticity, and we therefore applied the rank transformation (RT-1) procedure outlined by Conover \& Iman (1981). Pearson correlation analyses were used to evaluate relationships between (1) GPP and light-associated nutrient uptake (L subtracted from D hourly flux rates), (2) GPP and benthic chl $a$, and (3) GPP and macroalgal biomass (dwt calculated from wwt at time of flux measurements). To compare predicted and observed results of diversity in the mixed-faunal assemblage, we applied yielding equations according to Waldbusser et al. (2004). Measurable contributions to an effect (e.g. flux rate) per individual organism $\left(E_{i}\right)$ of species $i$ were calculated as:

$$
E_{i}=\left(M_{i}-A\right) / p_{i}
$$

where $M_{\mathrm{i}}$ is the value measured in the monospecific treatment, $A$ is the value measured in the control, and $p_{i}$ is the number of individuals in the treatment. The predicted value for the mixed-faunal assemblage $\left(E_{\mathrm{T}}\right)$ was then determined by:

$$
E_{\mathrm{T}}=A+\sum_{i}\left(E_{i} p_{i}\right)
$$

Yielding $\left(D_{\mathrm{T}}\right)$ values were derived from differences between observed $\left(O_{\mathrm{T}}\right)$ and predicted $\left(E_{\mathrm{T}}\right)$ values for the mixed-species treatment:

$$
D_{\mathrm{T}}=\left(O_{\mathrm{T}}-E_{\mathrm{T}}\right) / E_{\mathrm{T}}
$$

Non-zero values for $D_{\mathrm{T}}$ represent over-yielding (positive) or under-yielding (negative), indicating that organism effects in diverse assemblages are not simple, additive functions of performance in singlespecies treatments.

\section{RESULTS}

Organism recovery at the termination of each experiment was $100 \%$, with the exception of a failed acclimation in one Alitta microcosm (Expt III) that was subsequently omitted from statistical analysis. In Expt I only, an unintended polychaete colonization altered the number of replicates per treatment: the control was reduced to $\mathrm{n}=3$ and Alitta increased to $\mathrm{n}=5$.

\section{Nutrient release and benthic microalgae}

Sediments were a consistent source of $\mathrm{NH}_{4}^{+}$and $\mathrm{PO}_{4}{ }^{3-}$ to the water column in Expt I, but $\mathrm{NH}_{4}{ }^{+}$efflux 
was substantially reduced in Alitta (Table 1A, Fig. 2A). Daily $\mathrm{NO}_{3}{ }^{-}$fluxes were positive (i.e. equaling net efflux) for Alitta and Ilyanassa, and negative (i.e. equaling net uptake) for the control, Mya, and Mix (hourly rates displayed in Fig. 2). Daily fluxes were highest in Ilyanassa, by 1.7-fold for total DIN and 3.4fold for $\mathrm{PO}_{4}{ }^{3-}$ with respect to Alitta. Nutrient release was significantly lower in the light relative to the dark (Table 1A), with the following reductions under illumination: from 20 to $53 \%\left(\mathrm{NH}_{4}^{+}\right)$, from 43 to $93 \%$ (DIN), and from 64 to $93 \%\left(\mathrm{PO}_{4}{ }^{3-}\right)$. An interaction between faunal treatment and L/D condition was observed for $\mathrm{NO}_{3}{ }^{-}$(Table 1A), with dark efflux and light influx in all treatments except Ilyanassa, which exhibited constant efflux (Fig. 2B).

Table 1. Expt I. Results of 2-way ANOVA for (A) flux rates across the sediment-water interface for dissolved inorganic nitrogen (DIN) compounds and $\mathrm{PO}_{4}{ }^{3-}$. Results of 1-way ANOVA for (B) dissolved oxygen (DO) flux rates, including benthic oxygen consumption (BOC), net ecosystem metabolism (NEM), and gross primary productivity (GPP), in addition to (C) benthic microalgal chlorophyll a (chl a). Results of 2-way ANOVA for (D) $\mathrm{N}_{2}$ fixation rates. Significant results $(p<0.05)$ in bold

\begin{tabular}{|c|c|c|c|}
\hline Source & $\mathrm{df}$ & $F$ & $\mathrm{p}$ \\
\hline \multicolumn{4}{|l|}{ (A) Nutrient flux rates } \\
\hline \multicolumn{4}{|l|}{$\mathrm{NH}_{4}^{+}$} \\
\hline Incubation condition & 1,28 & 23.16 & $<0.001$ \\
\hline Treatment $\times$ Condition & 4,28 & 0.39 & 0.815 \\
\hline \multicolumn{4}{|l|}{$\mathrm{NO}_{3}^{-}$} \\
\hline Faunal treatment & 4,24 & 0.73 & 0.580 \\
\hline Incubation condition & 1,24 & 48.94 & $<0.001$ \\
\hline Treatment $\times$ Condition & 4,24 & 4.18 & 0.010 \\
\hline \multicolumn{4}{|l|}{ DIN (total) } \\
\hline Faunal treatment & 4,24 & 1.72 & 0.179 \\
\hline Incubation condition & 1,24 & 88.04 & $<0.001$ \\
\hline Treatment $\times$ Condition & 4,24 & 2.53 & 0.066 \\
\hline \multicolumn{4}{|l|}{$\mathrm{PO}_{4}{ }^{3-}$} \\
\hline Faunal treatment & 4,28 & 2.14 & 0.103 \\
\hline Incubation condition & 1,28 & 23.93 & $<0.001$ \\
\hline Treatment $\times$ Condition & 4,28 & 0.48 & 0.749 \\
\hline \multicolumn{4}{|l|}{ (B) DO flux rates } \\
\hline $\mathrm{BOC}$ & 4,15 & 2.58 & 0.080 \\
\hline NEM $^{a}$ & 4,15 & 3.26 & 0.041 \\
\hline $\mathrm{GPP}^{\mathrm{b}}$ & 4,15 & 2.33 & 0.104 \\
\hline \multicolumn{4}{|l|}{ (C) Benthic microalgae } \\
\hline $\mathrm{Chl} a^{\mathrm{b}}$ & 4,15 & 4.24 & 0.017 \\
\hline Chl a: phaeopigments & 4,15 & 2.84 & 0.062 \\
\hline \multicolumn{4}{|l|}{ (D) $\mathrm{N}_{2}$ fixation rates } \\
\hline \multicolumn{4}{|l|}{ Surface sediments } \\
\hline Faunal treatment & 2,26 & 1.11 & 0.345 \\
\hline Incubation condition & 2,26 & 51.44 & $<0.001$ \\
\hline Treatment $\times$ Condition & 4,26 & 0.36 & 0.837 \\
\hline \multicolumn{4}{|l|}{ Sub-surface sediments } \\
\hline Faunal treatment & 1,12 & 0.24 & 0.635 \\
\hline Incubation condition & 1,12 & 61.06 & $<0.001$ \\
\hline Treatment $\times$ Condition & 1,12 & 0.09 & 0.767 \\
\hline${ }^{\mathrm{a}} \log (x+10) ;{ }^{\mathrm{b}} 1 / x$ & & & \\
\hline
\end{tabular}
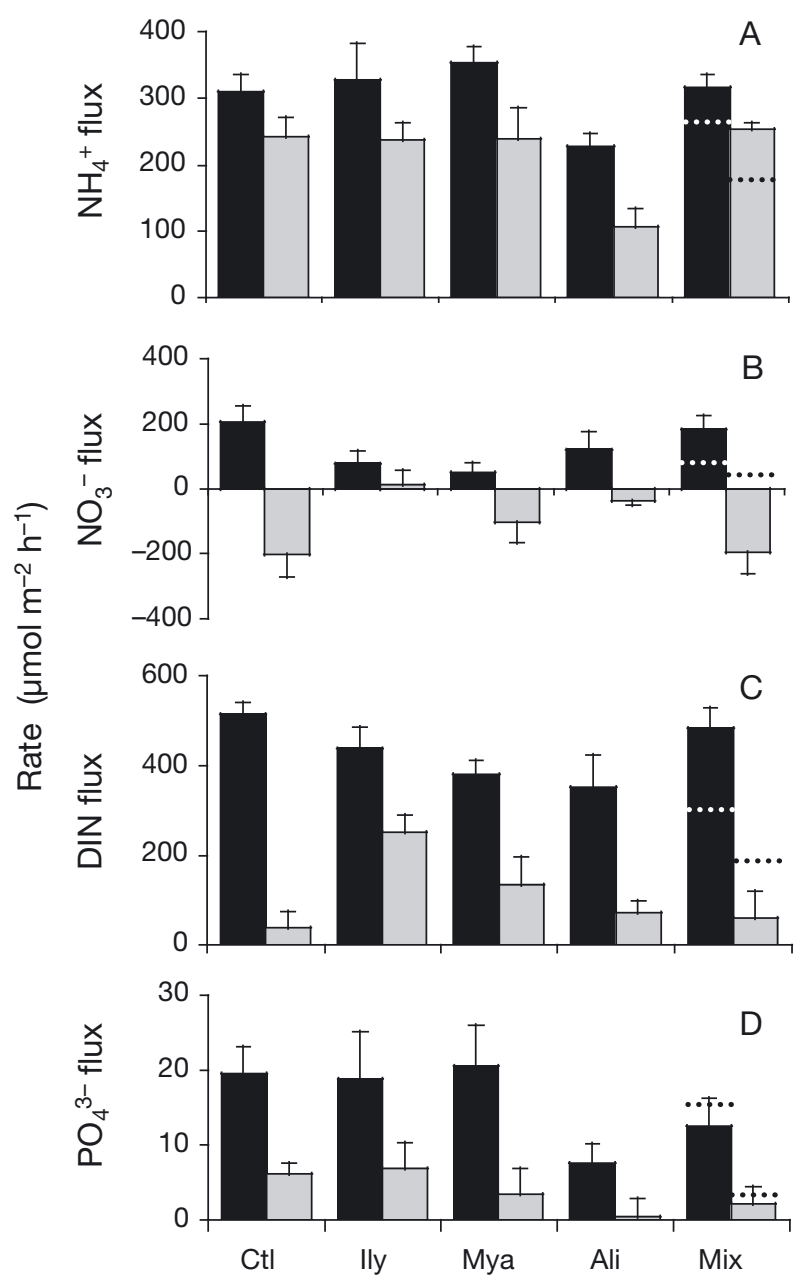

Fig. 2. Expt I. Sediment-water column hourly flux rates (mean $\pm \mathrm{SE}$ ) during dark (black bars) and light (gray bars) incubations for (A) $\mathrm{NH}_{4}{ }^{+}$, (B) $\mathrm{NO}_{3}{ }^{-}$, (C) total dissolved inorganic nitrogen (DIN), and (D) $\mathrm{PO}_{4}{ }^{3-}$. Positive values = sediment release; negative values = sediment uptake. Treatment codes: Ctl, control; Ily, Ilyanassa obsoleta; Mya, Mya arenaria; Ali, Alitta virens; Mix, mixed-fauna. Dotted lines in Mix indicate expected values based on yielding calculations. Note different scales on $y$-axes

All Expt I treatments were net heterotrophic, and BOC in microcosms containing fauna was enhanced from 7 to $30 \%$ relative to the control (Fig. 3A). NEM was most negative in Mix (Fig. 3B), which was significantly more heterotrophic than Alitta (Table 1B). GPP was greatest in Alitta and lowest in Mix (Fig. 3C), although differences were not significant (Table 1B). Light-associated reductions (D minus L hourly values) in $\mathrm{NH}_{4}{ }^{+}$efflux were positively correlated with GPP (Pearson's $\mathrm{R}=0.74, \mathrm{p}<0.001$ ), but there were no parallel correlations between GPP and $\mathrm{NO}_{3}{ }^{-}$(Pearson's $\mathrm{R}=0.02, \mathrm{p}>0.99$ ) or $\mathrm{PO}_{4}{ }^{3-}$ (Pearson's $\mathrm{R}=-0.13, \mathrm{p}=$ 0.61). Light-associated uptake of sediment-derived DIN could meet from 90 to $100 \%$ of calculated daytime 

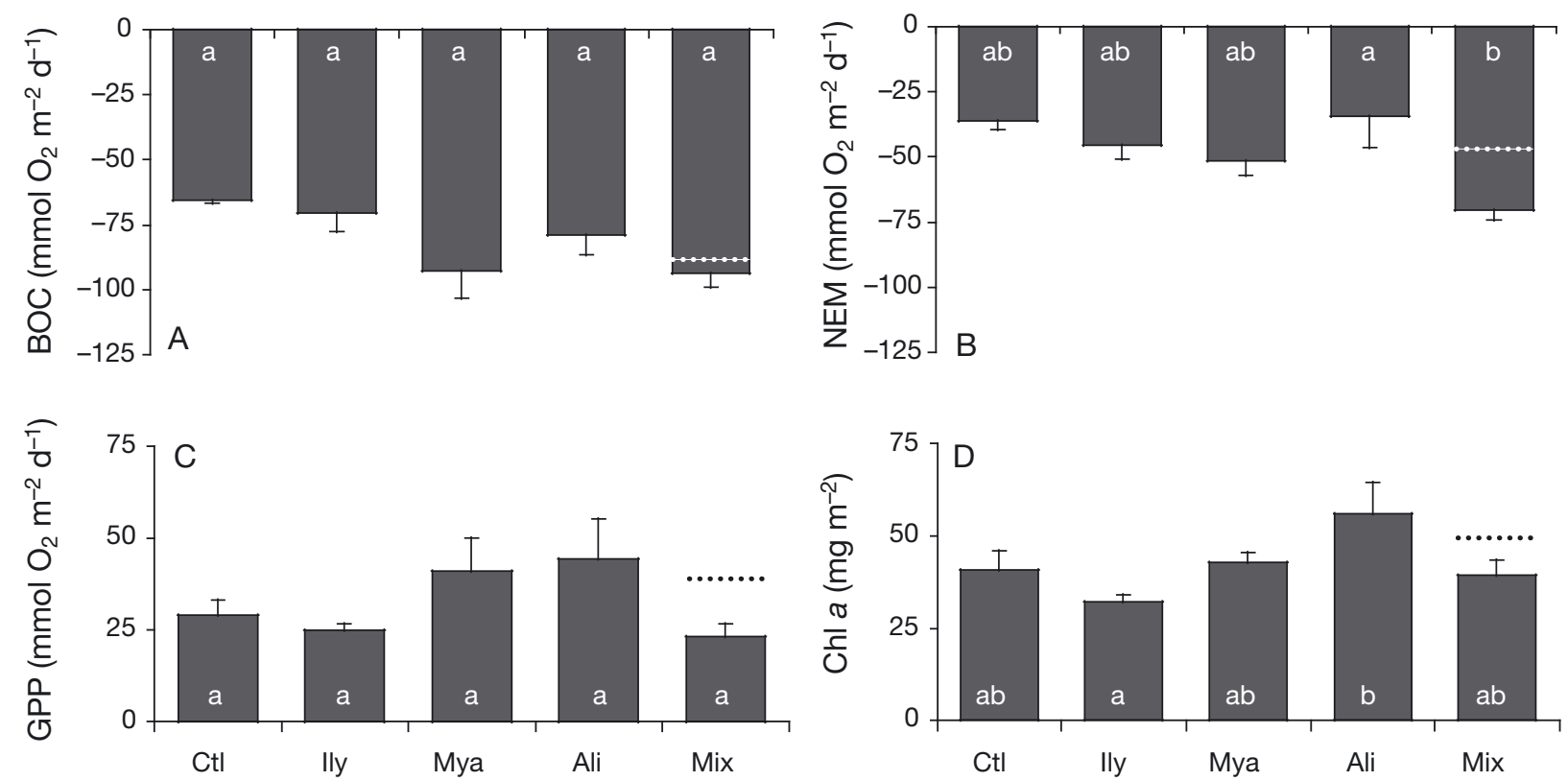

Fig. 3. Expt I. Daily rates (mean \pm SE) for (A) benthic oxygen consumption (BOC), (B) net ecosystem metabolism (NEM), and (C) gross primary productivity (GPP), in addition to (D) benthic chlorophyll a (chl a) in surface sediments. Treatment codes: Ctl, control; Ily, Ilyanassa obsoleta; Mya, Mya arenaria; Ali, Alitta virens; Mix, mixed-fauna. Dotted lines in Mix indicate expected values based on yielding calculations. Dissimilar lower-case letters inside bars denote significant differences (Tukey's HSD) between treatments

benthic microalgal $\mathrm{N}$ demand, which ranged from $2.6 \pm 0.4$ (Mix) to $4.9 \pm 1.2$ (Alitta) $\mathrm{mmol} \mathrm{m}^{-2} \mathrm{~d}^{-1}$.

Benthic chl a was also positively correlated with GPP (Pearson's $\mathrm{R}=0.71, \mathrm{p}<0.001$ ) and was significantly higher in Alitta than Ilyanassa (Table 1C, Fig. 3D). Microalgal turnover (chl a:phaeopigments) was highest in Alitta, although not significantly so (Table 1C). $\mathrm{N}_{2}$ fixation was greater in the dark than in the light (Table 1D) and was generally higher in surface sediments, although the relative importance of sulfatereducing bacteria to total $\mathrm{N}_{2}$ fixation (from 60 to $70 \%$ contribution) was similar between sediment depths (Table 2). Faunal effects on $\mathrm{N}_{2}$ fixation, however, were negligible (Table 1D).

\section{Macroalgal biomass and productivity}

While Gracilaria biomass declined over time in all treatments in Expt II (Fig. 4A), the decline was greatest

Table 2. Expt I. $\mathrm{N}_{2}$ fixation rates $\left(\mu \mathrm{mol} \mathrm{N} \mathrm{m} \mathrm{N}^{-2} \mathrm{~h}^{-1}\right)$ in surface $(0$ to $1 \mathrm{~cm})$ and subsurface (3 to $4 \mathrm{~cm}$ ) sediments in light, dark, and dark + sodium molybdate $(+\mathrm{Mo})$ incubation conditions. Values are mean $\pm \mathrm{SE}$

\begin{tabular}{|lcrrrrr|}
\hline \multirow{2}{*}{ Treatment } & \multicolumn{3}{c}{ Surface sediments } & & \multicolumn{2}{c|}{ Sub-surface sediments } \\
& \cline { 2 - 4 } & Light & Dark & Dark+Mo & Dark & Dark+Mo \\
\hline Control & $22.8 \pm 2.2$ & $32.5 \pm 4.3$ & $11.7 \pm 2.1$ & $17.3 \pm 0.9$ & $5.2 \pm 1.7$ \\
Alitta & $18.2 \pm 1.8$ & $30.4 \pm 2.4$ & $9.6 \pm 0.8$ & $16.1 \pm 1.9$ & $5.0 \pm 0.7$ \\
Ilyanassa & $21.2 \pm 4.6$ & $28.8 \pm 1.9$ & $11.5 \pm 1.7$ & & \\
\hline
\end{tabular}

in Alitta and Mix and least in Ilyanassa. Macroalgae in microcosms containing $A$. virens displayed clear evidence of grazing, coupled with redistribution of thalli into burrows; remaining thalli became increasingly fragmented and pigmentation shifted from dark red to pale yellow-brown until complete disappearance - in Alitta by Day 21 and in Mix by Day 28. In contrast, mean Gracilaria biomass in Ilyanassa was 2.4-fold greater than the control on Day 28, although values were similar at prior time-points. The significant pattern of higher biomass in the control and Ilyanassa relative to Alitta and Mix at each measurement (Table 3A) was reflected in the close correlation between GPP and macroalgal biomass (Pearson's R = 0.97, $\mathrm{p}<0.001$ ). We did not find any clear effects on macroalgae in Mya. Microcosms containing A. virens were net heterotrophic, and in comparison with Ilyanassa we observed greater rates of BOC and significantly lower NEM values (Table 3B, Fig. 5). At the termination of Expt II, only the control and Ilyanassa retained sufficient macroalgal tissue for elemental analyses, but no differences in $\% \mathrm{~N}$ or in $\mathrm{C}: \mathrm{N}$ were observed (McLenaghan 2009).

In Expt III, total macroalgal biomass increased in Ilyanassa $(+6 \%)$ yet ultimately declined in all other treatments (control: $-21 \%$, Mix: $-56 \%$, Alitta: $-80 \%)$. There were significant treatment effects on total biomass 


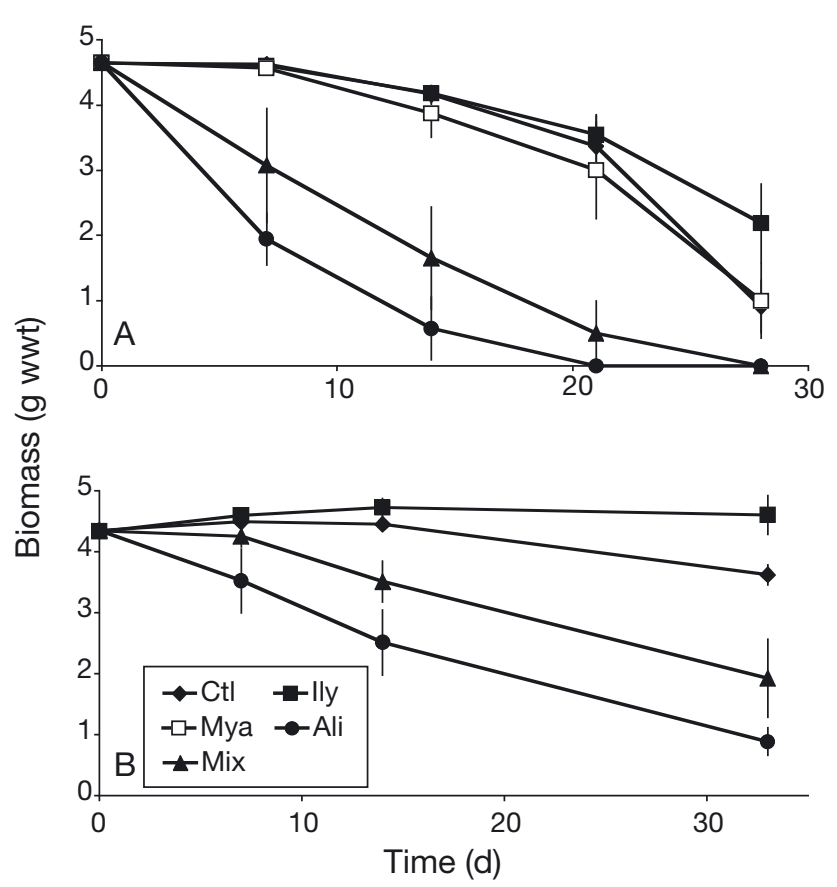

Fig. 4. (A) Biomass (mean \pm SE) over time of Gracilaria sp. in the Expt II macroalgal monoculture and (B) total biomass of the 3species macroalgal polyculture in Expt III. Treatment codes: Ctl, control; Ily, Ilyanassa obsoleta; Mya, Mya arenaria (Expt II, only); Ali, Alitta virens; Mix, mixed-fauna; wwt: wet weight

(Table 3C), with differences between Ilyanassa and Alitta at each time-point and between the control and Alitta on Days 14 and 33. As in Expt II, grazing and translocation of thalli by $A$. virens substantially diminished macroalgal standing stocks (Fig. 4B) and diversity by eliminating 2 of the 3 species from the seaweed polyculture. Individual macroalgal species displayed distinct chronological variations in biomass (Fig. 6). Fucus biomass peaked after 7 to $14 \mathrm{~d}$ in all treatments and then either remained constant (control and Ilyanassa) or declined to $61 \%$ (Alitta) or $74 \%$ (Mix) of the initial biomass by Day 33. In treatments that excluded A. virens, Gracilaria grew steadily throughout the experiment. Ulva declined slowly from Day 0 to 14 , followed by a more rapid reduction in biomass (from Day 14 to 33) that coincided with emergence of enlarged, circular perforations in thalli from all treatments. Although the control and Ilyanassa were statistically similar at all time-points, the final biomass of all macroalgal species was greatest in Ilyanassa. In sharp contrast, grazing by $A$. virens (Fig. 7) radically altered the patterns exhibited in the control (Table 3C), with maximum reductions in each species occurring sequentially in Alitta: (1) Gracilaria biomass decreased first (from Day 0 to 7), (2) Ulva was next (from Day 7 to 14), and (3) Fucus was last (from Day 14 to 33).
Table 3. Results of 1-way ANOVA for Expt II: (A) Gracilaria sp. biomass and (B) dissolved oxygen (DO) flux rates, including benthic oxygen consumption (BOC), net ecosystem metabolism (NEM), and gross primary productivity (GPP). Results of 1-way ANOVA for Expt III: (C) macroalgal biomass, (D) DO flux rates, and (E) tissue carbon:nitrogen $(\mathrm{C}: \mathrm{N})$ ratios and \% $\mathrm{N}$ of Fucus vesiculosus (all treatments) and Gracilaria sp. (control and Ilyanassa). Significant results $(\mathrm{p}<0.05)$ in bold

\begin{tabular}{|c|c|c|c|}
\hline Source & $\mathrm{df}$ & $F$ & $\mathrm{p}$ \\
\hline \multicolumn{4}{|c|}{ (A) Expt II: Gracilaria sp. biomass ${ }^{\mathrm{a}}$} \\
\hline Day 7 & 4,15 & 12.29 & $<0.001$ \\
\hline Day 14 & 4,15 & 8.71 & 0.001 \\
\hline Day 21 & 4,15 & 10.22 & $<0.001$ \\
\hline Day 28 & 4,15 & 10.25 & $<0.001$ \\
\hline \multicolumn{4}{|l|}{ (B) Expt II: DO flux rates } \\
\hline $\mathrm{BOC}$ & 4,15 & 7.04 & 0.028 \\
\hline NEM & 4,15 & 9.23 & 0.016 \\
\hline GPP & 4,15 & 7.33 & 0.025 \\
\hline \multicolumn{4}{|c|}{ (C) Expt III: Macroalgal biomass ${ }^{\mathrm{a}}$} \\
\hline \multicolumn{4}{|c|}{ Gracilaria sp. } \\
\hline Day 7 & 3,15 & 9.42 & 0.001 \\
\hline Day 14 & 3,15 & 9.87 & 0.001 \\
\hline Day 33 & 3,15 & 8.50 & 0.002 \\
\hline \multicolumn{4}{|l|}{ Ulva sp. } \\
\hline Day 7 & 3,15 & 2.69 & 0.084 \\
\hline Day 14 & 3,15 & 4.53 & 0.019 \\
\hline Day 33 & 3,15 & 3.21 & 0.053 \\
\hline \multicolumn{4}{|l|}{ Fucus vesiculosus } \\
\hline Day 7 & 3,15 & 0.36 & 0.785 \\
\hline Day 14 & 3,15 & 1.16 & 0.356 \\
\hline Day 33 & 3,15 & 6.07 & 0.006 \\
\hline \multicolumn{4}{|l|}{ Total macroalgal biomass } \\
\hline Day 7 & 3,15 & 5.34 & 0.011 \\
\hline Day 14 & 3,15 & 8.69 & 0.001 \\
\hline Day 33 & 3,15 & 12.13 & $<0.001$ \\
\hline \multicolumn{4}{|c|}{ (D) Expt III: DO flux rates } \\
\hline $\mathrm{BOC}$ & 3,15 & 16.87 & $<0.001$ \\
\hline NEM & 3,15 & 15.98 & $<0.001$ \\
\hline GPP & 3,15 & 5.69 & 0.008 \\
\hline \multicolumn{4}{|c|}{ (E) Expt III: tissue nutrients } \\
\hline Fucus vesiculosus $\mathrm{C}: \mathrm{N}$ & 3,15 & 12.38 & $<0.001$ \\
\hline Fucus vesiculosus \% $\mathrm{N}$ & 3,15 & 13.61 & $<0.001$ \\
\hline Gracilaria sp. C:N & 1,8 & 0.35 & 0.568 \\
\hline Gracilaria sp. \% $\mathrm{N}$ & 1,8 & 5.23 & 0.051 \\
\hline
\end{tabular}

In Expt III, Alitta again displayed significant trends of enhanced BOC, net heterotrophic metabolism, and lower GPP (Table 3D, Fig. 5). Although the effect of A. virens on BOC and total macroalgal biomass in Mix was apparent, we surprisingly observed greater GPP and slightly higher Ulva biomass in this treatment than in the control; GPP in Mix was most similar to Ilyanassa (Fig. 5F). The relationship between GPP and total macroalgal biomass in Expt III (Pearson's R = 0.47, p = 0.04 ) was weaker than the correlation displayed in the Expt II monoculture. The best predictor of GPP was Ulva biomass (Pearson's $\mathrm{R}=0.59, \mathrm{p}=0.01$ ), while Gracilaria (Pearson's $\mathrm{R}=0.32, \mathrm{p}=0.18$ ) and Fucus 

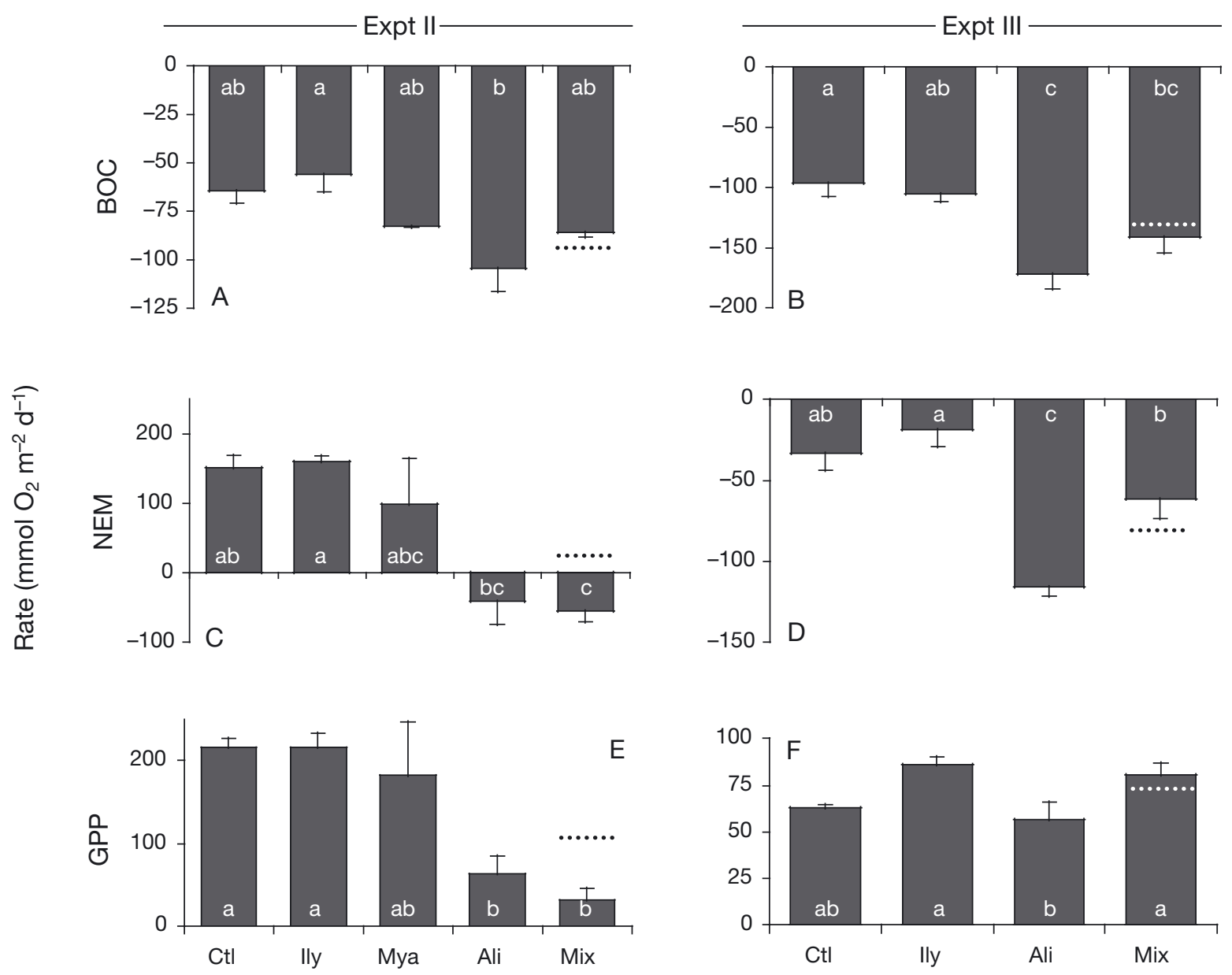

Fig. 5. Daily rates (mean $\pm \mathrm{SE}$ ) for benthic oxygen consumption (BOC) in (A) Expt II and (B) Expt III; for net ecosystem metabolism (NEM) in (C) Expt II and (D) Expt III, and for gross primary productivity (GPP) in (E) Expt II and (F) Expt III. Treatment codes: Ctl, control; Ily, Ilyanassa obsoleta; Mya, Mya arenaria (Expt II, only); Ali, Alitta virens; Mix, mixed-fauna. Dotted lines in Mix indicate expected values based on yielding calculations. Note different scales on $y$-axes. Dissimilar lower-case letters inside bars denote significant differences (Tukey's HSD) between treatments

(Pearson's $\mathrm{R}=-0.10, \mathrm{p}=0.68$ ) were not correlated. Sufficient tissue for elemental analysis was present in all microcosms for Fucus, and in Ilyanassa and the control for Gracilaria. We could not obtain adequate tissue for Ulva. Both Alitta and Mix showed significantly lower $\% \mathrm{~N}$ and higher $\mathrm{C}: \mathrm{N}$ in Fucus relative to the control and Ilyanassa (Table 3E, Fig. 8). Tissue \%N of Gracilaria was marginally higher in Ilyanassa (Table 3E; $\mathrm{p}=$ $0.051)$.

\section{Effects of faunal diversity}

Comparison of observed vs. predicted values for measured properties revealed that the effects of increasing diversity were highly variable (Table 4). For daily nutrient fluxes, $\mathrm{NO}_{3}{ }^{-}$under-yielded by $270 \%$ as net uptake occurred rather than efflux; $\mathrm{NH}_{4}{ }^{+}$release over-yielded by $25 \%$; and $\mathrm{PO}_{4}{ }^{3-}$ efflux was close to expected values $(-8 \%)$. Oxygen consumption was within 3 to $7 \%$ of predictions across experiments, while NEM deviated from predictions by $-53 \%$ (Expt I) and $-270 \%$ (Expt II), as driven by low productivity in faunal assemblages. In Expt III, however, NEM was $8 \%$ greater and GPP was $13 \%$ higher than expected. Benthic chl a under-yielded (16\%), as did final Gracilaria biomass in both the seaweed monoculture (100\%) and seaweed polyculture (61\%). Other macroalgal taxa, however, were within $5 \%$ (Ulva) to $15 \%$ (Fucus) of predicted biomass at the end of Expt III.

\section{DISCUSSION}

The invertebrates in our experiments exhibited species-specific controls over benthic algal communities 
and sediment nutrient release, with effects that have direct implications for ecosystem functioning. The polychaete Alitta virens created a series of negative feedbacks with macroalgal growth through (1) en-

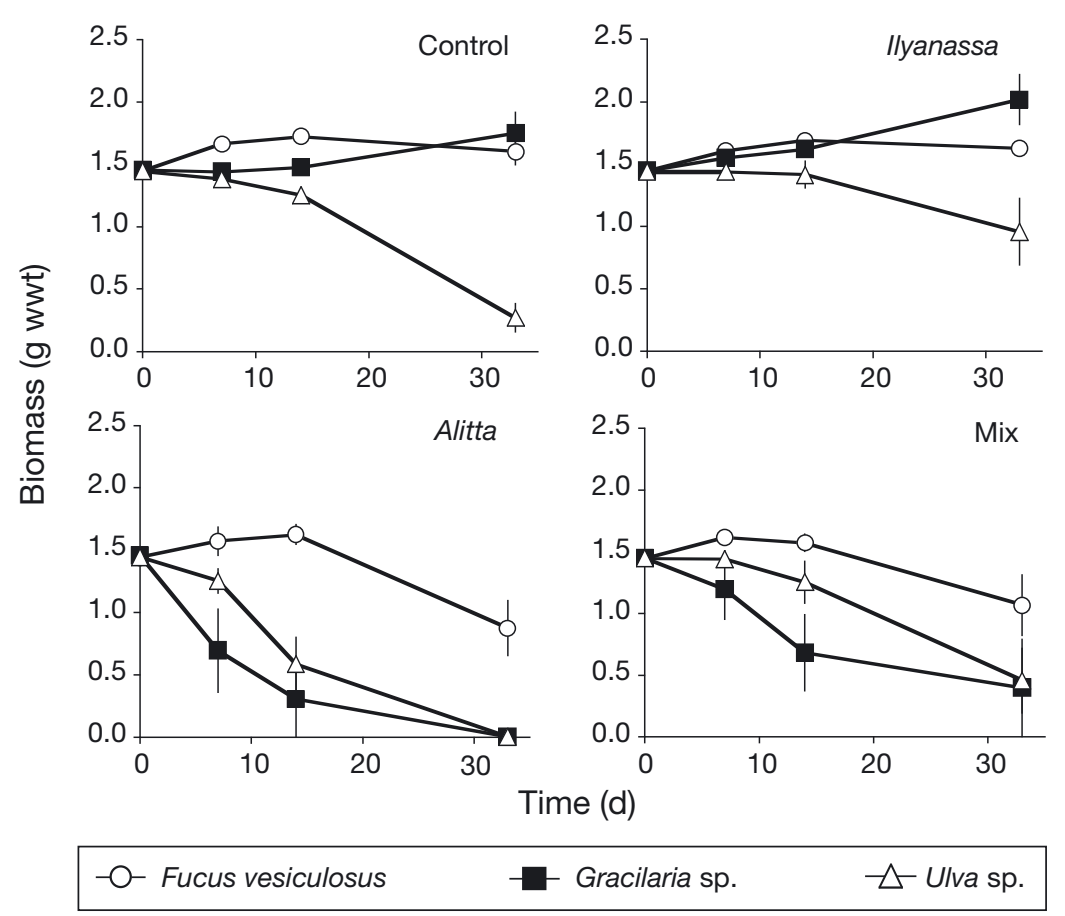

Fig. 6. Expt III. Biomass (mean \pm SE) of Fucus vesiculosus, Gracilaria sp., and Ulva sp. over time in the control, Ilyanassa obsoleta treatment (Ilyanassa), Alitta virens treatment (Alitta), and the mixed-fauna treatment (Mix). wwt: wet weight hancement of resource competition via stimulation of benthic microalgae, (2) inhibition of bottom-up nutrient supply (in particular, $\mathrm{NH}_{4}{ }^{+}$), and (3) direct grazing of thalli. In contrast, the gastropod Ilyanassa obsoleta supported macroalgal growth through (1) suppression of benthic microalgal communities, (2) maintenance of sediment nutrient release with promotion of continuous $\mathrm{NO}_{3}^{-}$efflux, and (3) moderate increases in macroalgal tissue $\% \mathrm{~N}$, specifically of Gracilaria in the seaweed polyculture. The bivalve Mya arenaria, in isolation, did not substantially alter nutrient or algal dynamics. In diverse faunal assemblages, benthic microalgal biomass and productivity appeared to be disproportionately reduced by $I$. obsoleta, while $A$. virens exerted dominant, negative controls on the proliferation of Gracilaria.

\section{Faunal feedbacks with nutrient supply and benthic microalgae}

Expt I demonstrated that invertebrates could act to either depress (Ilyanassa obsoleta) or stimulate (Alitta virens) benthic microalgal communities (Fig. 3), but that responses in faunal

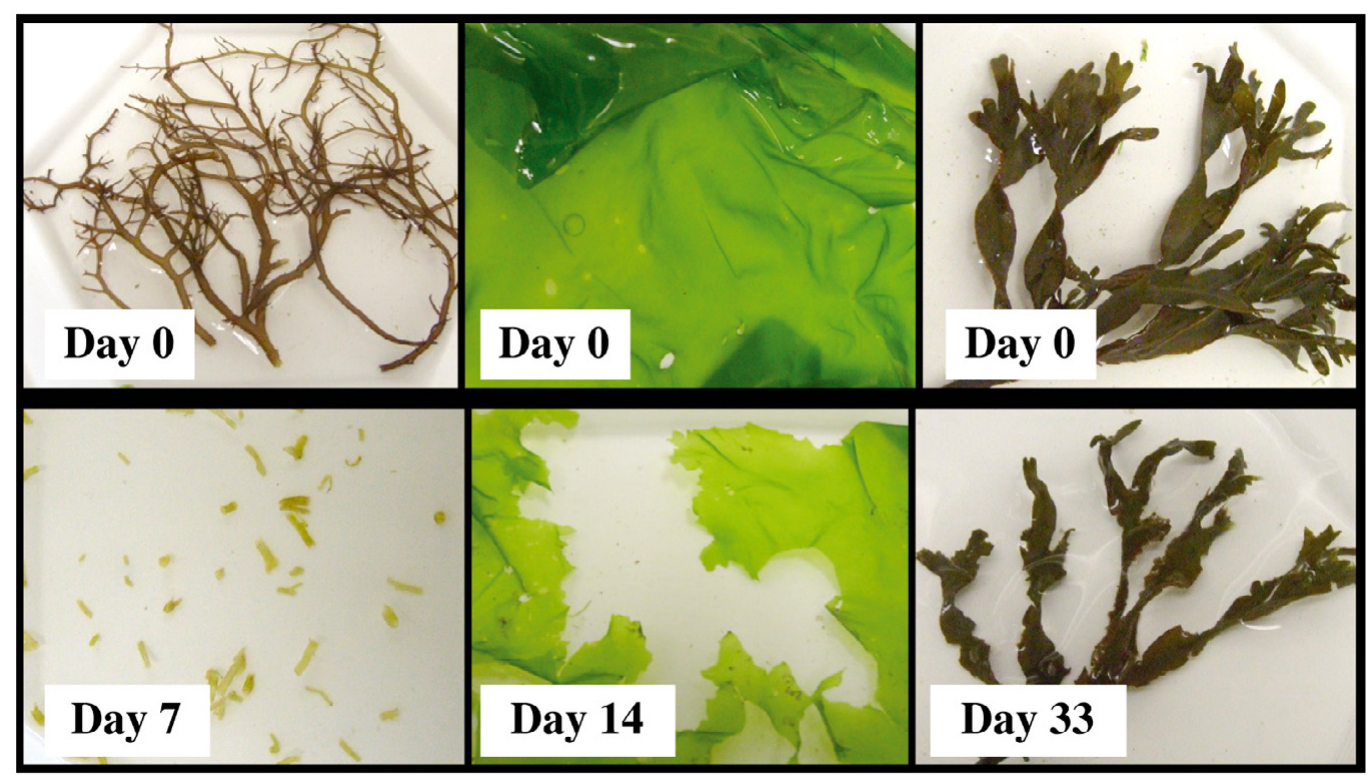

Gracilaria sp.

Ulva sp.

Fucus vesiculosus

Fig. 7. Expt III. Evidence of grazing by the polychaete Alitta virens upon thalli of Gracilaria sp. 7 d following addition of macroalgae to microcosms, Ulva sp. after $14 \mathrm{~d}$, and Fucus vesiculosus after $33 \mathrm{~d}$ 

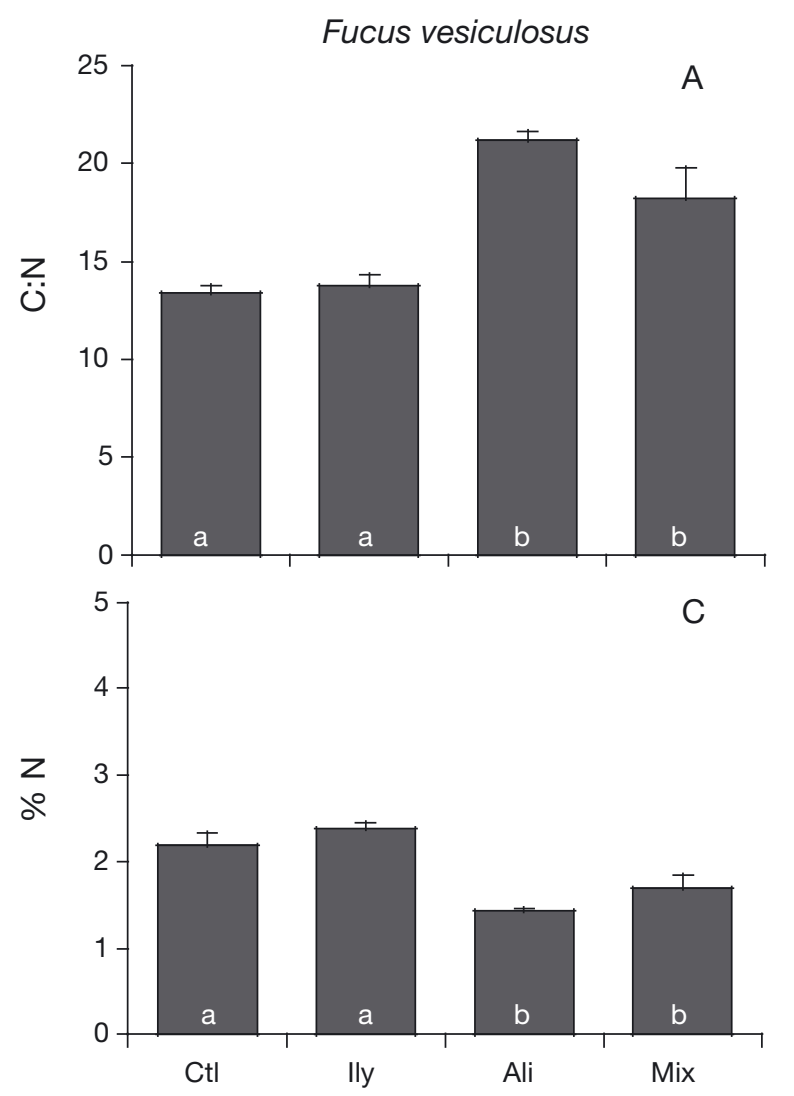

Gracilaria sp.
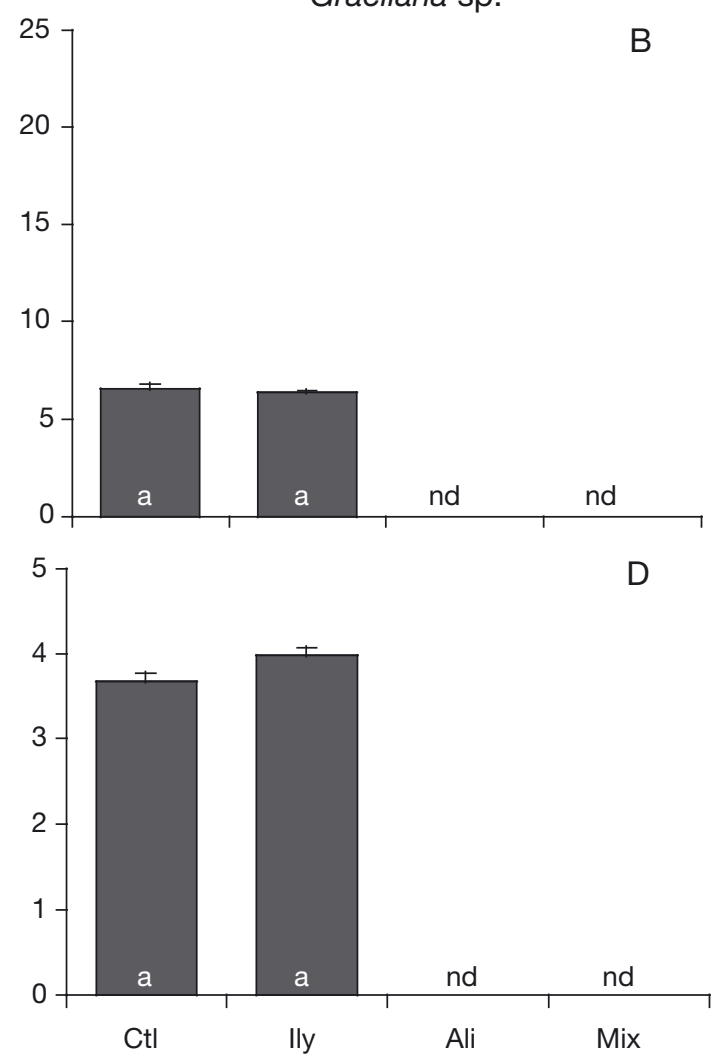

Fig. 8. Expt III. Mean values (+SE) for tissue carbon:nitrogen (C:N) and \%N content in Fucus vesiculosus and Gracilaria sp. at final measurements. Treatment codes: Ctl, control; Ily, Ilyanassa obsoleta; Ali, Alitta virens; Mix, mixed-fauna. nd: no data. Dissimilar lower-case letters inside bars denote significant differences (Tukey's HSD) between treatments

mixtures were not simple additive functions of performance in monospecific microcosms (Table 4). Our finding that $A$. virens supported the highest levels of benthic microalgal biomass, primary production, and turnover could be a result of intermediate-level disturbance of the sediment surface, potentially with selective removal of senescent microalgae. Others have found that nereidid polychaetes prompt higher turnover of benthic microalgal $\mathrm{C}$ and photopigments (Tang \& Kristensen 2007), which may have implications for succession in benthic microalgal communities if polychaetes promote new production. In contrast to these effects, our study and others using I. obsoleta at similar densities show effective decrease in benthic microalgal chl a and primary productivity (Pace et al. 1979, Connor et al. 1982). Moreover, I. obsoleta reduced GPP in our mixed-faunal assemblages despite the stimulatory effects of $A$. virens, and our yielding calculations (Table 4) suggest a particularly strong interaction between invertebrate diversity and benthic microalgal productivity, with an amplification of inhibitory effects by I. obsoleta. Andersen \& Kristensen (1988) also documented reduced primary production within assemblages that included $A$. virens and mudsnails (Hydrobia sp.), and attribute the decrease to interspecific competition. Field evidence further suggests that the foraging behavior and superior mobility of $I$. obsoleta enable the snail to more effectively compete for food resources and in turn reduce abundances of deposit-feeding polychaetes, thereby structuring the benthic community (Kelaher et al. 2003).

Regulation of benthic microalgal production also translates into indirect faunal control of nutrient uptake, as evidenced by the tight correlations between GPP and both (1) chl $a$ and (2) L/D differences in $\mathrm{NH}_{4}{ }^{+}$ efflux. Benthic microalgal communities exercise a critical role in regulating nutrient fluxes at the sedimentwater interface (Tyler et al. 2001, 2003), and the depression of $\mathrm{NH}_{4}{ }^{+}$release by Alitta virens after $25 \mathrm{~d}$ (Fig. 2A) may be partially attributed to enhancement of microalgal uptake. Our observations of $\mathrm{NH}_{4}^{+}$efflux reduction differ from others that have demonstrated stimulatory effects by nereidid polychaetes over shorter experimental time scales (from 1 to $20 d_{\text {; }}$ e.g. Andersen \& Kristensen 1988, Hansen \& Kristensen 1997, Mermillod-Blondin et al. 2004, Michaud et al. 
Table 4. Results of yielding calculations performed according to Waldbusser et al. (2004), comparing observed vs. expected values in the mixed-faunal treatment (Mix). Positive values indicate over-yielding (i.e. greater magnitude than predicted in Mix, based upon single-species treatments). Negative values represent under-yielding. BOC: benthic oxygen consumption; NEM: net ecosystem metabolism; GPP: gross primary productivity. Values for macroalgal biomass were calculated from final measurements. In Expts I and II; underyielding indicates that Mix was more heterotrophic than predicted, and over-yielding indicates that Mix was less heterotrophic

\begin{tabular}{|lr|}
\hline Source & Yielding (\%) \\
\hline Expt I & \\
$\mathrm{BOC}$ & 7 \\
$\mathrm{NEM}$ & -53 \\
$\mathrm{GPP}$ & -44 \\
$\mathrm{NH}_{4}{ }^{+}$flux (daily) & 25 \\
$\mathrm{NO}_{3}{ }^{-}$flux (daily) & -270 \\
$\mathrm{PO}_{4}{ }^{3-}$ flux (daily) & -9 \\
$\mathrm{Chlorophyll} a$ Expt II & -16 \\
$\mathrm{BOC}$ & \\
$\mathrm{NEM}$ & -5 \\
GPP & -270 \\
Gracilaria sp. biomass & -75 \\
Expt III & -100 \\
BOC & \\
NEM & 3 \\
GPP & 8 \\
Gracilaria sp. biomass & 13 \\
Ulva sp. biomass & -61 \\
Fucus vesiculosus biomass & -5 \\
Total macroalgal biomass & -15 \\
& -30 \\
\hline
\end{tabular}

2006). Measurements performed shortly after polychaete colonization may capture a period of enhanced mineralization and mobilization of solutes to the water column, as Hansen \& Kristensen (1997) observed: initial pulses of nutrient release and oxygen consumption with Hediste (formerly Nereis) diversicolor, followed by a decrease and relative stabilization after 15 to $20 \mathrm{~d}$. While early effects may be driven by the initial stimulation of sediment microbial communities (e.g. Andersen \& Kristensen 1988, Mermillod-Blondin et al. 2004), coupled with effective burrow flushing (Henriksen et al. 1983, Hansen \& Kristensen 1997, MermillodBlondin et al. 2004), A. virens might also diminish longer-term efflux through promotion of benthic microalgal N uptake. Moreover, nereidids could decrease nutrient release via reduction of microbial mineralization (Henriksen et al. 1983), through direct consumption of sediment OM. A companion investigation by Mahl (2009) showed that after $1 \mathrm{mo}, A$. virens density was negatively correlated with both porewater $\mathrm{NH}_{4}{ }^{+}$and flux of sediment-derived $\mathrm{NH}_{4}{ }^{+}$(excluding faunal excretion), potentially due to increased competition for OM among polychaetes and microbes, or enhancement of $\mathrm{NH}_{4}{ }^{+}$transformation to $\mathrm{NO}_{3}{ }^{-}$.

Our results suggest that $\mathrm{NO}_{3}{ }^{-}$exchange was affected by feedbacks between the benthic microbial community and species-specific functional characteristics of invertebrates (Table 1A), as depth of bioturbation and formation of burrows can dictate the extent of nitrification and subsequent denitrification (Henriksen et al. 1983, Michaud et al. 2006). Continuous release of $\mathrm{NO}_{3}{ }^{-}$ in Ilyanassa throughout both dark and light periods is likely attributable to disturbance of benthic microalgae and enhanced oxygenation of surface sediments, thus promoting nitrifying bacteria in this zone. In contrast, deeper-dwelling burrowers like Alitta virens and Mya arenaria may either increase (A. virens) or decrease (M. arenaria) the net daily efflux of $\mathrm{NO}_{3}{ }^{-}$by altering $\mathrm{NH}_{4}{ }^{+}$production, sediment oxygenation, and coupled nitrification-denitrification.

We anticipated that grazing pressure and controls on $\mathrm{N}$ availability would impact benthic $\mathrm{N}_{2}$ fixation, as topdown limitations on fixation have been illustrated in pelagic systems (zooplankton grazers; Marino et al. 2002) and in lacustrine benthos (snails; Gettel et al. 2007), yet we detected no effects. Benthic $\mathrm{N}_{2}$ fixation was negligible compared with net $\mathrm{NH}_{4}{ }^{+}$fluxes $(<10 \%$ of overall release), and in general, rates within nonvegetated, estuarine sediments of low to moderate organic content are considered to be of minor importance (Howarth et al. 1988). Below the sediment surface, nereidids may influence microbial communities by favoring aerobes over sulfate-reducers in burrow structures (Mermillod-Blondin et al. 2004), although we observed no such effects on $\mathrm{N}_{2}$ fixation by sulfate reducers. Faunal regulation of nutrient availability did not appear to be linked with direct or indirect controls on sediment $\mathrm{N}_{2}$ fixation.

\section{Faunal mediation of macroalgal dynamics}

Sediments function as a significant internal reservoir of nutrients to support primary production (Tyler et al. 2003, Sundbäck et al. 2003, Kamer et al. 2004), and active control of sediment nutrient release by invertebrates may be important in determining macroalgal proliferation. The promotion of continuous $\mathrm{NO}_{3}{ }^{-}$efflux in Ilyanassa (Fig. 2) appeared to stimulate growth (or to slow decline) of all macroalgal species (Figs. 4 \& 6), and the marginally higher Gracilaria tissue $\mathrm{N}$ content in Expt III (Table 3E) suggests that nutrient enhancement played a role. Facilitation of macroalgae by bioturbating gastropods has been reported elsewhere, as Fong \& Desmond (1997) noted that horn snails Cerithidea californica increased growth and $\mathrm{N}$ content of 
Ulva expansa tissue via excretion and transfer of nutrients from the benthos. Furthermore, Giannotti \& McGlathery (2001) illustrated that $I$. obsoleta enhanced tissue N content of U. lactuca by 40 to $80 \%$, although the snails ultimately prompted the demise of the macroalgae. In our study, autogenic reduction in Ulva biomass caused in part by emergence of circular perforations (in presence and absence of fauna) was unrelated to grazing effects. Perforations in Ulva fronds are associated with reproduction and subsequent biomass loss occurs in mid-summer (Niesenbaum 1988), coinciding with the timing of our experiments. Using the same genera of annual seaweeds as the present study, Teichberg et al. (2008) demonstrated that early-summer growth of Ulva in the Waquoit Bay estuaries near WFH is superior to Gracilaria under enriched conditions, yet Gracilaria can rely on internal nutrient stores in depleted waters. While thalli of both taxa have a higher affinity for $\mathrm{NH}_{4}{ }^{+}$, Ulva can grow quickly with addition of either $\mathrm{NO}_{3}{ }^{-}$or $\mathrm{NH}_{4}{ }^{+}$(Teichberg et al. 2008), which may partially explain why loss of Ulva biomass in Expt III was stemmed in the presence of I. obsoleta.

In contrast to the fertilization effect of snails, changes in Gracilaria pigmentation in the presence of Alitta virens suggest a reduction of tissue $\mathrm{N}$. This could not be confirmed by elemental analyses due to complete removal of thalli by polychaetes, but is supported by our observation of reduced $\mathrm{NH}_{4}{ }^{+}$supply in Expt I. Others have shown that N-deficient Gracilaria thalli lose phycoerythrin (red-brown pigment) in both laboratory (Ryther et al. 1981) and field populations (Tyler \& McGlathery 2006). Furthermore, reduced $\% \mathrm{~N}$ and increased C:N in Fucus from microcosms containing $A$. virens (Fig. 8) could be related to higher phlorotannin concentrations. These secondary metabolites tend to be inversely correlated with tissue $\mathrm{N}$ content (Pavia \& Toth 2000), with phlorotannin production increasing under low-nutrient conditions and in response to grazing (Yates \& Peckol 1993). The observed decrease in tissue $\% \mathrm{~N}$ might be explained by reduction of sediment $\mathrm{NH}_{4}{ }^{+}$release or consumption of high- $\mathrm{N}$ apical tissues. We recommend further research to clarify the potentially complex relationship between polychaetes, nutrient availability, and chemical defenses.

The few studies to report on seaweed grazing by nereidid polychaetes have documented substantial reductions in biomass, with results varying according to macroalgal taxa. For example, others have observed biomass declines and/or translocation of Ulva spp. due to activities of Hediste diversicolor (Raffaelli 2000, Nordstrom et al. 2006, Engelsen \& Pihl 2008), while a $7 \mathrm{~d}$ experiment showed a non-significant decrease in Fucus vesiculosus in monoculture (Nordstrom et al. 2006). In our Expt III, grazing on Fucus was not docu- mented until Days 14 to 33, when other species were either absent or less abundant, thus illustrating the importance of longer-term monitoring and inclusion of multiple seaweed taxa. Despite substantial redistribution of macroalgae into sediments, no subsequent increases in OM content were documented (McLenaghan 2009). Tissue not consumed directly by polychaetes likely was subject to rapid decomposition, as remaining thalli showed intensive fragmentation (Fig. 7).

Grazers tend to prefer macroalgal taxa with relatively higher nutrient content (Hauxwell et al. 1998, Worm et al. 2000), and furthermore, may selectively consume $\mathrm{N}$ - and P-rich specimens when presented with both ambient and enriched thalli of the same species (Kraufvelin et al. 2006). While grazers tend to restrict dominance of palatable taxa under oligotrophic conditions, annuals may displace perennials as nutrient loads to estuaries increase and grazing potential is overwhelmed (Worm et al. 2000). Of the seaweeds included in our polyculture experiment, dominance patterns in the field are likely dictated by a combination of nutrient availability, potential growth rates, timing of reproduction, and susceptibility to grazing.

\section{Biodiversity and ecosystem functioning}

Community composition of autotrophs can be a critical determinant of ecosystem processes such as primary productivity, in both terrestrial systems (Hooper \& Vitousek 1997) and marine environments (Bruno et al. 2005). We have demonstrated that manipulation of faunal and seaweed diversity has both direct and indirect consequences for ecosystem functions, particularly in relation to productivity and composition of the autotrophic community. In simple systems including either zero or 1 seaweed species, there were substantial effects of faunal diversity on benthic microalgae and macroalgae, as well as ecosystem metabolism. When we incorporated multi-species assemblages of seaweeds, total macroalgal biomass and productivity in the mixed-fauna microcosms were close to predicted values, and clear species-specific patterns emerged: we consistently observed swift reduction of Gracilaria by Alitta virens, while Ilyanassa obsoleta promoted bloom-forming taxa such as Ulva. Moreover, species identity may be a more important factor than macroalgal richness in regulating overall production (Kraufvelin et al. 2010), as opportunistic taxa such as Ulva can be more productive in the absence of other macroalgae (Bruno et al. 2005). In support of these prior findings on the importance of macroalgal species identity, we found that GPP during Expt III was best explained by the biomass of a single taxon (Ulva) within assem- 
blages. Total macroalgal biomass was only correlated with GPP in a seaweed monoculture (Expt II), as inclusion of multiple macroalgal species confounded this relationship. Our experiments highlight important species-specific effects and emphasize the need to incorporate increasingly complex assemblages across multiple trophic levels in biodiversity studies.

In conclusion, these results help to further our understanding of feedbacks between functional traits of invertebrates and ecosystem processes. Ilyanassa obsoleta, a common bioturbator, may accelerate eutrophication by diminishing benthic microalgal biomass, sustaining efflux of nutrients, and indirectly promoting macroalgal growth. Conversely, the bioirrigating polychaete Alitta virens may buffer initial impacts of nutrient enrichment by stimulating benthic microalgae, inhibiting $\mathrm{NH}_{4}{ }^{+}$release, and efficiently reducing bloom-forming seaweeds through grazing. Other species, such as Mya arenaria, may produce only limited effects on nutrient and algal dynamics. In light of increasing eutrophication and widespread changes in species distribution on a global scale, particularly in coastal regions, it is increasingly urgent to clarify the mechanistic relationships between ecosystem functioning and both invertebrate and macroalgal diversity.

Acknowledgements. We are grateful to M. Hayn, C. Funk, S. Kelsey, M. Ferdie Muth, L. Reynolds, M. Kozlowski, and C. Scheiner for assistance in the field and laboratory, and to T. Duncan for sharing his knowledge of benthic invertebrate distributions within the study site. The Marine Biological Laboratory provided logistical support, and we especially thank the following people: A. Giblin, K. Foreman, K. McGlathery, and P. Berg. The manuscript was improved by the comments of 3 anonymous reviewers. This material is based on work funded by the National Science Foundation under grants awarded to A.C.T. (OCE 0727642) and R.W.H. (EAR 0420575).

\section{LITERATURE CITED}

An S, Joye SB (2001) Enhancement of coupled nitrificationdenitrification by benthic photosynthesis in shallow estuarine sediments. Limnol Oceanogr 46:62-74

> Andersen FO, Kristensen E (1988) The influence of macrofauna on estuarine benthic community metabolism: a microcosm study. Mar Biol 99:591-603

Bruno JF, Boyer KE, Duffy JE, Lee SC, Kertesz JS (2005) Effects of macroalgal species identity and richness on primary production in benthic marine communities. Ecol Lett 8:1165-1174

> Bruno JF, Boyer KE, Duffy JE, Lee SC (2008) Relative and interactive effects of plant and grazer richness in a benthic marine community. Ecology 89:2518-2528

> Connor MS, Teal JM, Valiela I (1982) The effect of feeding by mud snails, Ilyanassa obsoleta (Say), on the structure and metabolism of a laboratory benthic algal community. J Exp Mar Biol Ecol 65:29-45

Conover WJ, Iman RL (1981) Rank transformations as a bridge between parametric and nonparametric statistics. Am Stat 35:124-129
Curtis LA, Hurd LE (1979) On the broad nutritional requirements of the mud snail, Ilyanassa (Nassarius) obsoleta (Say), and its polytrophic role in the food web. J Exp Mar Biol Ecol 41:289-297

Emmerson MC, Solan M, Emes C, Paterson DM, Raffaelli D (2001) Consistent patterns and the idiosyncratic effects of biodiversity in marine ecosystems. Nature 411:73-77

Engelsen A, Pihl L (2008) Grazing effects by Nereis diversicolor on development and growth of green algal mats. J Sea Res 59:228-236

Fong P, Desmond JS (1997) The effect of a horn snail on Ulva expansa (Chlorophyta): Consumer or facilitator of growth? J Phycol 33:353-359

Gettel GM, Giblin AE, Howarth RW (2007) The effects of grazing by the snail, Lymnaea elodes, on benthic $\mathrm{N}_{2}$ fixation and primary production in oligotrophic, arctic lakes. Limnol Oceanogr 52:2398-2409

Giannotti AL, McGlathery KJ (2001) Consumption of Ulva lactuca (Chlorophyta) by the omnivorous mudsnail Ilyanassa obsoleta (Say). J Phycol 37:209-215

Gosner KL (1971) Guide to identification of marine and estuarine invertebrates: Cape Hatteras to the Bay of Fundy. Wiley Interscience, New York, NY

> Hansen K, Kristensen E (1997) Impact of macrofaunal recolonization on benthic metabolism and nutrient fluxes in a shallow marine sediment previously overgrown with macroalgal mats. Estuar Coast Shelf Sci 45:613-628

> Hauxwell J, McClelland J, Behr PJ, Valiela I (1998) Relative importance of grazing and nutrient controls of macroalgal biomass in three temperate shallow estuaries. Estuaries 21:347-360

> Havens KE, Hauxwell J, Tyler AC, Thomas S and others (2001) Complex interactions between autotrophs in shallow marine and freshwater ecosystems: implications for community responses to nutrient stress. Environ Pollut 113:95-107

> Hay ME, Fenical W (1988) Marine plant-herbivore interactions: the ecology of chemical defense. Annu Rev Ecol Syst 19:111-145

Henriksen K, Rasmussen MB, Jensen A (1983) Effect of bioturbation on microbial nitrogen transformations in the sediment and fluxes of ammonium and nitrate to the overlaying water. Ecol Bull 35:193-205

Hooper DU, Vitousek PM (1997) The effects of plant composition and diversity on ecosystem processes. Science 277 : 1302-1305

> Howarth RW (1988) Nutrient limitation of net primary production in marine ecosystems. Annu Rev Ecol Syst 19:89-110

Howarth RW, Marino R, Lane J, Cole JJ (1988) Nitrogen fixation in freshwater, estuarine, and marine ecosystems: 1. Rates and importance. Limnol Oceanogr 33:669-687

Howes BL, Kelley SW, Ramsey JS, Samimy RI, Schlezinger DR, Eichner EM (2006) Linked watershed-embayment model to determine critical nitrogen loading thresholds for West Falmouth Harbor, Massachusetts. Massachusetts Estuaries Project, Massachusetts Department of Environmental Protection, Boston, MA

> Kamer K, Fong P, Kennison RL, Schiff K (2004) The relative importance of sediment and water column supplies of nutrients to the growth and tissue nutrient content of the green macroalga Enteromorpha intestinalis along an estuarine resource gradient. Aquat Ecol 38:45-56

> Karlson K, Hulth S, Ringdahl K, Rosenberg R (2005) Experimental recolonisation of Baltic Sea reduced sediments: survival of benthic macrofauna and effects on nutrient cycling. Mar Ecol Prog Ser 294:35-49

Kelaher BP, Levinton JS, Hoch JM (2003) Foraging by the mud snail, Ilyanassa obsoleta (Say), modulates spatial 
variation in benthic community structure. J Exp Mar Biol Ecol 292:139-157

Kraufvelin P, Salovius S, Christie H, Moy FE, Karez R, Pedersen MF (2006) Eutrophication-induced changes in benthic algae affect the behaviour and fitness of the marine amphipod Gammarus locusta. Aquat Bot 84:199-209

Kraufvelin P, Lindholm A, Pedersen MF, Kirkerud LA, Bonsdorff E (2010) Biomass, diversity and production of rocky shore macroalgae at two nutrient enrichment and wave action levels. Mar Biol 157:29-47

$>$ Lorenzen CJ (1967) Determination of chlorophyll and pheopigments: spectrophotometric equations. Limnol Oceanogr $12: 343-346$

Lubchenco J (1978) Plant species diversity in a marine intertidal community: importance of herbivore food preference and algal competitive abilities. Am Nat 112:23-39

Mahl UH (2009) Effects of the density of co-occurring bivalves (Mya arenaria) and deep-burrowing polychaetes (Nereis virens) on benthic fluxes and the concentrations of ammonium and soluble sulfides in sediment porewater. MS thesis, Cornell University, Ithaca, NY

> Marino R, Chan F, Howarth RW, Pace M, Likens GE (2002) Ecological and biogeochemical interactions constrain planktonic nitrogen fixation in estuaries. Ecosystems 5: 719-725

McLenaghan NA (2009) Benthic macroinvertebrate diversity in a shallow estuary: controls on nutrient and algal dynamics. MS thesis, Rochester Institute of Technology, Rochester, NY

Mermillod-Blondin F, Rosenberg R, Francois-Carcaillet F, Norling K, Mauclaire L (2004) Influence of bioturbation by three benthic infaunal species on microbial communities and biogeochemical processes in marine sediment. Aquat Microb Ecol 36:271-284

Michaud E, Desrosiers G, Mermillod-Blondin F, Sundby B, Stora G (2006) The functional group approach to bioturbation: II. The effects of the Macoma balthica community on fluxes of nutrients and dissolved organic carbon across the sedimentwater interface. J Exp Mar Biol Ecol 337:178-189

> Murphy J, Riley JP (1962) A modified single solution method for the determination of phosphate in natural waters. Anal Chim Acta 27:31-36

Niesenbaum RA (1988) The ecology of sporulation by the macroalga Ulva lactuca L. (Chlorophyceae). Aquat Bot 32: $155-166$

Nordstrom M, Bonsdorff E, Salovius S (2006) The impact of infauna (Nereis diversicolor and Saduria entomon) on the redistribution and biomass of macroalgae on marine soft bottoms. J Exp Mar Biol Ecol 333:58-70

Norling K, Rosenberg R, Hulth S, Gremare A, Bonsdorff E (2007) Importance of functional biodiversity and speciesspecific traits of benthic fauna for ecosystem functions in marine sediment. Mar Ecol Prog Ser 332:11-23

Pace ML, Shimmel S, Darley WM (1979) The effect of grazing by a gastropod, Nassarius obsoletus, on the benthic microbial community of a salt marsh mudflat. Estuar Coast Mar Sci 9:121-134

Pavia H, Toth GB (2000) Influence of light and nitrogen on the phlorotannin content of the brown seaweeds Ascophyllum nodosum and Fucus vesiculosus. Hydrobiologia 440: 299-305

Pettibone MH (1963) Marine polychaete worms of the New England region. I. Families Aphrodiditae through Trochochaetidae. Bull US Natl Mus 227:1-356

Raffaelli D (2000) Interactions between macro-algal mats and invertebrates in the Ythan estuary, Aberdeenshire, Scotland. Helgol Mar Res 54:71-79

Editorial responsibility: Morten Pedersen,

Roskilde, Denmark
Rhoads DC (1974) Organism-sediment relations on the muddy sea floor. Oceanogr Mar Biol Annu Rev 12: 263-300

> Rysgaard S, Christensen PB, Nielsen LP (1995) Seasonal variation in nitrification and denitrification in estuarine sediment colonized by benthic microalgae and bioturbating infauna. Mar Ecol Prog Ser 126:111-121

Ryther JH, Corwin N, Debusk TA, Williams LD (1981) Nitrogen uptake and storage by the red alga Gracilaria tikvahiae (McLachlan, 1979). Aquaculture 26:107-115

Smith RL, Klug MJ (1981) Reduction of sulfur compounds in the sediments of a eutrophic lake basin. Appl Environ Microbiol 41:1230-1237

Solorzano L (1969) Determination of ammonia in natural waters by the phenol hypochlorite method. Limnol Oceanogr 14:799-801

Stewart WD, Fitzgerald GP, Burris RH (1967) In situ studies on $\mathrm{N}_{2}$ fixation using the acetylene reduction technique. Proc Natl Acad Sci USA 58:2071-2078

Strickland JH, Parsons TR (1972) A practical handbook of seawater analysis. Bull Fish Res Board Canada 167

Sundbäck K, Enoksson V, Granéli W, Pettersson K (1991) Influence of sublittoral microphytobenthos on the oxygen and nutrient flux between sediment and water: a laboratory continuous-flow study. Mar Ecol Prog Ser 74:263-279

Sundbäck K, Miles A, Hulth S, Pihl L, Engstrom P, Selander E, Svenson A (2003) Importance of benthic nutrient regeneration during initiation of macroalgal blooms in shallow bays. Mar Ecol Prog Ser 246:115-126

Sundbäck K, Linares F, Larson F, Wulff A, Engelsen A (2004) Benthic nitrogen fluxes along a depth gradient in a microtidal fjord: the role of denitrification and microphytobenthos. Limnol Oceanogr 49:1095-1107

Tang M, Kristensen E (2007) Impact of microphytobenthos and macroinfauna on temporal variation of benthic metabolism in shallow coastal sediments. J Exp Mar Biol Ecol 349:99-112

Teichberg M, Fox SE, Aguilar C, Olsen YS, Valiela I (2008) Macroalgal response to experimental nutrient enrichment in shallow coastal waters: growth, internal nutrient pools, and isotopic signatures. Mar Ecol Prog Ser 368:117-126

Tyler AC, McGlathery KJ (2006) Uptake and release of nitrogen by the macroalgae Gracilaria vermiculophylla (Rhodophyta). J Phycol 42:515-525

- Tyler AC, McGlathery KJ, Anderson IC (2001) Macroalgae mediation of dissolved organic nitrogen fluxes in a temperate coastal lagoon. Estuar Coast Shelf Sci 53:155-168

- Tyler AC, McGlathery KJ, Anderson IC (2003) Benthic algae control sediment-water column fluxes of organic and inorganic nitrogen compounds in a temperate lagoon. Limnol Oceanogr 48:2125-2137

- Valiela I, McClelland J, Hauxwell J, Behr PJ, Hersh D, Foreman K (1997) Macroalgal blooms in shallow estuaries: controls and ecophysiological and ecosystem consequences. Limnol Oceanogr 42:1105-1118

> Waldbusser GG, Marinelli RL, Whitlatch RB, Visscher PT (2004) The effects of infaunal biodiversity on biogeochemistry of coastal marine sediments. Limnol Oceanogr 49: 1482-1492

- Worm B, Lotze HK, Sommer U (2000) Coastal food web structure, carbon storage, and nitrogen retention regulated by consumer pressure and nutrient loading. Limnol Oceanogr 45:339-349

Yates JL, Peckol P (1993) Effects of nutrient availability and herbivory on polyphenolics in the seaweed Fucus vesiculosus. Ecology 74:1757-1766

Submitted: June 14, 2010; Accepted: January 10, 2011

Proofs received from author(s): March 11, 2011 